\title{
A Macroeconomic Approach to Estimating Effective Tax Rates in South Africa
}

\author{
Adedeji Amusa
}

Department of Economics, University of Pretoria

\section{ABSTRACT}

Using data contained in South Africa's national accounts and revenue statistics, this paper constructs time-series of effective tax rates for consumption, capital income, and labour income. The macroeconomic approach allows for a detailed breakdown of tax revenue accruing to general government and the corresponding aggregate tax bases. The methodology used also yields effective rate estimates that can be considered as being consistent with tax distortions faced by a representative economic agent within a general equilibrium framework. Correlation analysis reveals that savings (as a percentage of GDP) is negatively correlated with both capital income and labour income tax rates. Investment (as a percentage of GDP) is positively correlated with the capital income tax rate, an outcome suggestive of the direct relationship between volatile capital inflows into South Africa and capital tax revenue.

JEL H20, 21, 30, 50

\section{INTRODUCTION}

Most analyses of tax policies has been geared towards the formulation of a tax system capable of providing, in the most efficient and equitable way possible, adequate revenue to finance the required level of government expenditure. The literature on public finance and macroeconomic effects of fiscal policies suggests that a key component of economic decision-making is the use and application of distortionary taxation (Mendoza et al., 1994).

Given the phenomenal rise in the global integration of economies of single nations, it has become imperative that domestic tax policies (especially those of developing nations) play a critical role in stimulating investment and economic growth. As developing countries integrate with the global economy, the development of effective and efficient tax collection systems that generate sufficient government revenue will aid in the reduction of excessive public sector borrowing, while catering to perceptions of foreign investors (Tanzi \& Zee, 2000; Aaron et al., 1999). Despite the wide acceptance of taxation as an 
important policy tool, limitations in measuring relevant tax rates have hindered in-depth analysis of the macroeconomic impact of alternative tax policies aimed at providing the required impetus for promoting economic growth.

The provision of reliable measures of tax rates is essential for two main reasons. First, reliable tax rate estimates are required to develop quantitative analysis and applications of theories related to taxation, thereby helping in the transformation of theory into an adequate policy-making tool. Second, the construction of reliable tax rate estimates are necessary for macroeconomic modelling, especially in the assessment of implications of significant fiscal policy changes such as tax harmonisation in economic blocs, fiscal deficit reduction and allocation of government expenditures aimed at providing socio-economic reforms (Mendoza et al., 1994).

Most previous studies on the construction of effective tax rates and the extension of the rates in analysing implications of tax policy on growth and business cycles have however, been conducted for developed countries or a mix of developing countries (see for example, Greenwood and Huffman, 1991; Easterly \& Rebelo, 1993 and Mendoza et al., 1994). None of these studies has provided specific investigations into constructing tax rates for developing countries. Yet, developing countries especially middle-income, emerging market economies such as South Africa present a special case to test. Given South Africa's socioeconomic and political history, the efficient mobilisation and maximisation of tax revenue represents a critical policy objective. An effective tax system would aid the government's objectives of allocating investment funds towards improving levels of physical and human capital, and addressing the backlogs in delivery of socio-economic infrastructure, especially among previously disadvantaged groups.

\subsection{Outline of paper}

This study provides a number of contributions to the present literature. The paper seeks to compute time-series estimates of effective tax rates on consumption, capital income, and labour income for South Africa using the methodology developed by Lucas (1990) and Razin and Sadka (1993). The main advantage of this method lies in its simplicity, as it utilises readily available information contained in national accounts and revenue statistics. The use of available macroeconomic data ensures that (i) the net effect of existing rules related to credit, exemptions and deductions are taken into account; (ii) a distinction is made between taxes on labour income and taxes on capital income, and (iii) there is incorporation of such taxes as property taxes and social security contributions that are not included on individual income tax returns (Mendoza et al., 1994). 
In addition, the construction of reliable estimates of effective tax rates will benefit empirical research geared towards contributing to policies seeking to enhance South Africa's tax system. For example, empirical studies on modelling tax collection, forecasting tax revenues or analysing the implications of changes in tax revenue patterns on stimulating economic growth are indicative of the potential practical use to which reliable estimates of effective tax rates can be put to. To our knowledge, specific studies utilising macroeconomic data in constructing effective tax estimates for South Africa do not exist at present.

It is thus the intention of this paper to present estimates of effective tax rates on major taxes, covering the period between 1990 and $2002^{1}$. The rest of the paper is organised into five sections. Section 2 discusses relevant literature and describes the methodology used to compute effective tax rates, while Section 3 introduces the theoretical foundation and methodology. Section 4 presents model estimations of the relevant effective tax rates while section 5 deals with underlying data issues. Section 6 reports the results of the estimated tax rates while section 7 concludes.

\section{LITERATURE REVIEW}

A number of studies have advanced different methodologies in constructing time-series data for effective and average tax rates on income and consumption. Using data from United States, United Kingdom, West Germany and Sweden, King and Fullerton (1984) developed a methodology that computed capital income tax rates as the difference between post-tax and pre-tax rates of return on specific investment projects. In their approach, the pre-tax rate of return is defined as the value of the marginal rate of return (MRR). The MRR of an investment project is calculated as the rate of return that equates the expected discounted present value of future after-tax profits with a project's costs (where the costs take into account grants, allowances and the rate of depreciation).

To apply the methodology defined above, a detailed set of information is required. Such information relates to statutory taxes on corporate and individual income, form of income (interest, dividend income etc,), tax exemptions and accounting for depreciation of investment/capital goods. Reviewing studies that have applied the King-Fullerton approach ${ }^{2}$, Mendoza et al. (1994) acknowledges that the methodology provides accurate measures of effective marginal tax on investments carried out at the microeconomic level. However, a significant drawback of the approach lies in its difficulty to transform the method into an aggregate model that captures macroeconomic phenomena such as anticipated inflation, inflation indexing and exchange rates, all of which affect tax bases. 
Analysing fiscal policies and economic growth for a cross-section of countries, Easterly and Rebelo (1993) computed average tax rates as ratios of tax revenues to taxable capacities (or the tax base), where average taxes are proxied by the ratio of total individual income taxes to personal income, and the ratio of total tax revenue from income, profits and capital gains to GDP. This method, however, fails to make a clear distinction between different sources of tax revenue and the corresponding tax bases.

In terms of country specific estimates of tax rates, studies by Joines (1981), Seater (1985), and Barro and Sahasakul (1986) have provided estimates of aggregate individual tax rates for the United States. In general, these studies adopt a similar approach to King and Fullerton by calculating aggregate marginal tax rates as a weighted average of tax rates per tax bracket, where the weights used are based on the share of income in each tax bracket's total income. A significant drawback of this approach is the non-provision of data that gives a detailed breakdown of revenue and corresponding tax rates related to labour, and capital income (Mendoza et al., 1994).

\section{THEORETICAL FOUNDATION AND METHODOLOGY}

\subsection{Theoretical exposition}

The framework for computing effective tax rates is largely based on the approach of estimating marginal tax rates at the microeconomic level. The theoretical concept of extending this micro level analysis to the national or aggregate levels has been the major thrust of studies by Lucas (1990) and Razin and Sadka (1993). This foundation has been modified and extended in Mendoza et al. (1994) and begins by assuming that the economy can be aggregated into three goods: consumption (c), labour (l) and capital (k). Government expenditure can be classified into transfer payments, wage payments, and purchases of goods while tax revenue is disaggregated into taxes on labour income, taxes on capital income, and taxes on consumption (or excise taxes).

Congruent with the disaggregation of expenditure and revenue, transfers (denoted as $b$ ) and purchases of goods by the government sector (denoted as $g$ ) can be represented as three-dimensional vectors. The allocation of each good to households' consumption is represented by the vector $\boldsymbol{h}=\left(h_{c}, h_{l}, h_{k}\right)$ while exogenous government policy regarding consumption of each good is denoted by the vector $\boldsymbol{g}=\left(g_{c}, g_{l}, g_{k}\right)$. This implies that to produce $\boldsymbol{c}$, firms rely on households to supply $k$ and $l$, while government finances its expenditures by imposing taxes on consumption, capital and labour income. 
The imposition of taxes by the government yields two price vectors: the consumer's post-tax price vector represented as $\boldsymbol{p}=\left(p_{c}, p_{l,} p_{k}\right)$ and the producer's pre-tax price vector denoted by $\boldsymbol{q}=\left(q_{c}, q_{l}, q_{k}\right)$ respectively. The difference between consumer and producer prices $\boldsymbol{t}=\boldsymbol{p}-\boldsymbol{q}$ gives the specific tax rate vector $\boldsymbol{t}=\left(t_{c}, t_{l}, t_{k}\right)$, where the specific tax rate is measured per unit of each of the three goods. If $t_{c}$ is assumed to be positive, it indicates that consumption is taxed rather than subsidised. When labour and capital incomes are taxed, the consumers' after-tax price for both commodities is typically lower than their producer pre-tax prices thereby making both $t_{l}$ and $t_{k}$ negative i.e., wages and capital income before tax exceed wages and capital income after tax. Ad valorem taxes can therefore be computed as $\tau_{i}=t_{i} / q_{i}$ (where $\mathrm{i}=\mathrm{c}, \mathrm{l}, \mathrm{k}$ ) and the corresponding vector for ad valorem taxes is denoted as $\tau=\left(\tau_{c}, \tau_{i,}, \tau_{k}\right)$.

With the price vectors $\boldsymbol{p}$ and $\boldsymbol{q}$ not readily available, measures of the relevant tax rates are approximated by multiplying $t_{i}$ and $q_{i}$ by an appropriate quantity measure, thus allowing for the utilisation of figures relating to tax revenues and the tax base rather than prices. To obtain the appropriate quantity measures, an examination of the household's budget constraint is required. This is represented schematically as:

$$
p(h-e-b)=q \cdot y-p_{c} D
$$

where the three-dimensional vectors $h, e, b$ and $y$ denote gross consumption, possible endowments, government transfers, and net output respectively. The net consumption (or purchase) vector on which the specific tax vector $t$ applies, is captured by $h-e-b$. For labour goods, households' net purchase of labour denoted as $h_{l}-e_{l}-b_{l}\left(=h_{l}-e_{l}\right)$ is negative ${ }^{3}$. In addition, $y_{c}$ which represents private sector output of the consumption good, is positive while $y_{l}$ and $y_{k}$ representing labour and capital (production) inputs, respectively, are both negative. A lump-sum tax used to finance any government deficit ${ }^{4}$ is defined by $p_{c} D$. Subsequently, q.y represents the value of net output in producer prices, measuring profits that form part of household income. Based on the theoretical exposition above, the relevant ad-valorem tax rates can be specified as:

$$
\begin{aligned}
\tau_{c} & =\frac{p_{c} y_{c}-q_{c} y_{c}}{q_{c} y_{c}} \\
\tau_{l} & =\frac{q_{l}\left(e_{l}-h_{l}\right)-p_{l}\left(e_{l}-h_{l}\right)}{q_{l}\left(e_{l}-h_{l}\right)} \\
\tau_{k} & =\frac{-q_{k} y_{k}-\left(p_{k} y_{k}\right)}{-q_{k} y_{k}}
\end{aligned}
$$


where the numerators in the above equations denote the difference between pretax and post-tax valuation of consumption, labour income and capital income, respectively. The denominators are valued at pre-tax prices and relate to measures of the tax base (i.e. consumption and income) affected by each tax. The use of pre- and after tax valuation of income and prices results in aggregate effective tax rates consistent with realised average tax rates. As these tax rates are sourced from national accounts and revenue statistics, they represent summations of information regarding statutory taxes, credits, exemptions and deductions, and therefore capture the overall burden of each tax (Mendoza et al., 1994).

\section{MODEL ESTIMATION}

\subsection{Effective tax rate on consumption}

n estimating the effective tax rate pertaining to consumption, this study follows studies by Razin and Sadka (1993) and Mendoza et al. (1994) that utilise a representative agent framework. This framework assumes a representative household involved in purchasing an aggregate consumption good and paying an ad-valorem tax. The effective tax rate on sales of consumption goods is estimated as:

$$
\tau_{c}=\left[\frac{D T G S}{C+G-G W-D T G S}\right] \times 100
$$

where DTGS $^{5}=$ domestic taxes on goods and services

$\mathrm{C}=$ Private final consumption expenditure

$\mathrm{G}=$ Government final consumption expenditure

$\mathrm{GW}=$ Compensation of employees paid by producers of government services.

The numerator captures revenue accruing from indirect taxation. By definition, the numerator equals the difference between the nominal value of total consumption at pre-tax and after-tax prices, and the denominator denotes pre-tax value of consumption, i.e. the tax base. As government payments of indirect taxes only apply to its purchases of goods and non-factor services, compensation of government employees is deducted from overall government expenditure. 


\subsection{Effective tax rate on labour income}

There are a number of factors affecting reliable computations of effective tax rate on labour income. For example, due to the fact that tax returns are filed to cover all of a tax payer's income, the manner in which data on income taxes are compiled do not take into account the origin of the income. Also, income tax data fail to provide a detailed breakdown of individual income tax revenue in terms of labour and capital income (Mendoza et al., 1994; Easterly \& Rebelo, 1993). In South Africa's case, the somewhat detailed separation of national accounts regarding the economic activities of households, business and government sector allows us to overcome some of these shortcomings.

To compute the effective tax rate on income, we first calculate households' average tax rate on total income:

$$
\tau_{h}=\left[\frac{T H I P}{O S P U E+P E I+W}\right]
$$

where

THIP $=$ taxes on income, profits, and capital gains of households

OSPUE = operating surplus of private unincorporated enterprises

PEI = households' property and entrepreneurial income

$\mathrm{W}=$ wages and salaries of households.

The tax rate on the representative agent's total income is thus defined as the ratio of individual tax revenue to pre-tax household income. The individual's income tax revenue is obtained from the difference between (aggregate) post-tax and pre-tax individual income where the latter is defined as the sum of wage and non-wage individual income, i.e. the denominator in equation (6). Estimating the revenue from income tax on wages and salaries as $\tau_{h} W$, the effective tax rate on labour income is computed as:

$$
\tau_{l}=\left[\frac{\tau_{h} W+T S C+T P W}{W+E C S}\right]
$$

where TSC $=$ total social security contribution

TPW $=$ taxes on payroll and workforce

ECS = employers contribution to social security.

From equation (7) above, calculation of effective income tax rates encompasses payroll taxes and expands the tax base to include all social security contributions as part of revenues obtained from taxing labour income. 


\subsection{Effective tax rate on capital income}

To estimate the tax rate on capital income, we first derive the capital income tax on individuals as $\tau_{h}(O S P U E+P E I)$, where $P E I$ includes capital income in the form of dividends, interest, rents and royalties. The effective tax rate on capital income can thus be calculated as:

$$
\tau_{k}=\left[\frac{\tau_{h}(O S P U E+P E I)+T O C+T O I P+T O F T}{O S}\right] \times 100
$$

where TOC= taxes on income, profits, and capital gains of corporations

TOIP $=$ taxes on immovable property

TOFT $=$ taxes on financial and capital transactions

OS = total operating surplus of the economy.

In equation (8) above, the numerator captures payments of capital income by households' and corporations, revenue from taxes imposed on financial transactions and recurrent taxes on immovable property, and represents the difference between post- and pre-tax levels of capital income. The operating surplus of the entire economy can be viewed as the pre-tax value (or tax base) of capital. ${ }^{6}$

\section{DATA SOURCES AND DATA ISSUES}

For the most part, many of the required macroeconomic data are readily available in the SARB's Quarterly Bulletin. However, since this study draws upon a methodology applied to OECD countries, there is a need to revise variables used when extending this study to South Africa's case. From equation (6), the tax base of household income should include the operating surplus of private unincorporated businesses, and this implies that informal sector activities are accounted for in the compilation of national accounts statistics. With an estimated output of over R32 billion, the informal sector in South Africa accounts for about 7 per cent of total GDP and employs about 1.8 million people. Despite these figures, it is quite difficult to ascertain true profits from informal sector activities. As South Africa's national accounts have no stated figures or estimates of informal sector economic activities, the study excludes from its analyses, the operating surplus of private unincorporated businesses.

The calculation of the effective tax rate on labour income requires the inclusion of all social security contributions, employers' contributions to social security 
and payroll taxes. In practice, social security contributions are meant to provide a safety net and source of income for citizens either unable to find gainful employment, or temporarily unemployed. While the present government provides some form of social funding especially to old age persons and disadvantaged citizens, comprehensive welfare schemes are non-existent in South Africa ${ }^{7}$. Data related to the South African government's finance statistics of social security funds is used as a proxy for total social security contributions ${ }^{8}$. In the same vein, employers' contributions to social security are non-existent in South Africa, and are, therefore, excluded from computations. Payroll taxes are a relatively new occurrence in South Africa. Introduced at the beginning of the 2000/01 financial year, the payroll tax is intended to fund the skills development initiative (SDI) with the overall objective of the initiative being the provision of training and improving the employment prospects of previously disadvantaged persons ${ }^{9}$.

One of the variables required in estimating the tax rate on capital income is the recurrent tax on immovable property. Like employers' contributions to social security and operating surplus of unincorporated household ventures, neither data nor proxies exist for taxes on immovable property. Hence, this variable is excluded from the analysis. Taxes on financial and capital transactions are proxied by taxes on retirement funds, donations, estate duties and marketable securities all of which are listed as "other" under taxes on income, profits and property in the South African national accounts statistics.

Given the above issues, this study acknowledges the possibility that estimates of effective tax rates of consumption, capital income and labour income for South Africa may be overstated or understated. By using a macroeconomic approach that clearly isolates the different sources of tax revenues and tax bases, and utilising available data contained in revenue statistics, the derived tax rate estimates will at least approximate actual estimates if, data corresponding to all variables were complete and available for South Africa. As such, the study retains its significance and remains a starting point upon which other studies could build.

\section{RESULTS}

The estimates of South African effective tax rates for consumption, capital income, and labour income over the period 1990 - 2001 are plotted in Figure 1. 
Figure 1 Effective tax rates of consumption, labour and capital: South Africa, 1990-2001

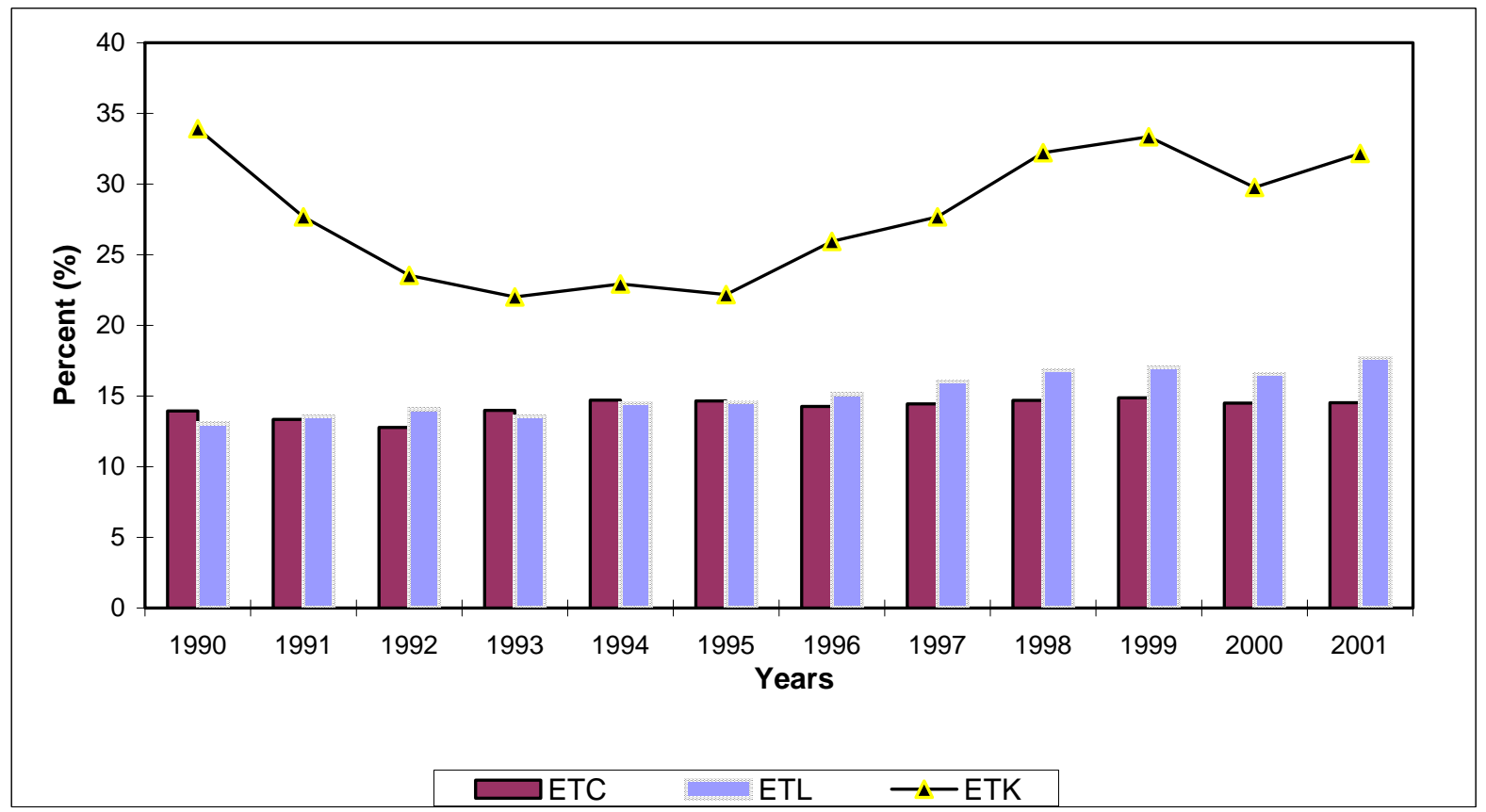

Keynote: ETC, ETL and ETK are effective tax rates for consumption, labour and capital respectively

Source: See Table 1

The effective tax rates on consumption displays a constant trend averaging 14 per cent while the effective rates on labour income indicates a slightly increasing trend, averaging 15 per cent over the sample period. The effective tax rate on capital shows some fluctuations, which can be traced to a number of internal and external socio-economic and political events. In the years leading up to the 1994 general elections, negative sentiments on the part of domestic and international investors, wary of potential political instability and South Africa becoming another failed African state, resulted in large capital outflows. The commitment of the new government in pursuing viable macroeconomic policies, a stable political environment, and liberalization policies (such as the gradual relaxation of capital and exchange controls) has had a positive impact on capital inflows into South Africa (Masters, 2001; Nowak, 2001).

However, as an emerging market-economy, South Africa remains prone to investor sentiments and market contagion emanating from economic crises that beset other emerging market-economies ${ }^{10}$. In effect, South Africa's emerging market status has led to significant increases in the volatility of capital inflows and, in turn, caused fluctuations in the revenue generated from taxes imposed on capital income. The increasing trend in income tax reflects the post-1994 increase in the employment of South Africa's non-white population, an 
occurrence that has broadened the distribution of income, and the income base. In addition, the strengthening and enhancement of the South African Revenue Service (SARS) administrative capabilities, especially in the area of income tax, has enabled higher revenues to be generated from income.

The results obtained show that for South Africa, taxes on capital income exceeded those of consumption and labour income (see Appendix A). Over the sample period, effective tax rates averaged 14, 15 and 28 per cent for consumption, labour income and capital income respectively. This finding seems to indicate that if labour and consumption are taxed less (more), South African authorities tend to tax capital more (less). Using a common sample correlation exercise, it is noted that the tax rate on capital is negatively correlated with savings (-0.07) and positively correlated with investment rates (0.42).

Table 1 Effective tax rates for consumption, labour income and capital income (in per cent)

\begin{tabular}{||c|c|c|c|}
\hline Year & Consumption & Labour income & Capital income \\
\hline 1990 & 13.9 & 13.1 & 33.9 \\
\hline 1991 & 13.3 & 13.6 & 27.7 \\
\hline 1992 & 12.8 & 14.1 & 23.5 \\
\hline 1993 & 14.0 & 13.5 & 22.0 \\
\hline 1994 & 14.7 & 14.5 & 23.0 \\
\hline 1995 & 14.6 & 14.5 & 22.2 \\
\hline 1996 & 14.3 & 15.1 & 26.0 \\
\hline 1997 & 14.4 & 16.0 & 27.7 \\
\hline 1998 & 14.7 & 16.8 & 32.2 \\
\hline 1999 & 14.9 & 17.0 & 33.3 \\
\hline 2000 & 14.5 & 16.6 & 29.8 \\
\hline 2001 & 14.5 & 17.7 & 32.2 \\
\hline
\end{tabular}

Source: Author's estimates as described in the text

The positive relationship between capital tax rates and investment might be a reflection of South African authorities' increased utilisation of tax revenue towards investments in capital projects and infrastructure, a scenario that has complemented private sector investment and activities. However, it is more likely that the relationship reflects the positive correlation between capital taxes and capital flows, i.e. increased (decreased) capital (or investment) flows lead to increased (decreased) capital tax revenues. The correlation between taxes on labour income and savings is negative (-0.83), confirming theoretical 
expectations that taxes on labour income tends to reduce the savings of employees.

\section{CONCLUSIONS}

Following studies by Razin and Sadka (1993) and Mendoza et al. (1994), this paper presents a methodology for estimating effective tax rates for labour income, capital income, and consumption based on macroeconomic data contained in South Africa's national income accounts and revenue statistics. The constructed time-series will serve as useful data in research related to dynamic macroeconomic models examining the implications of fiscal policies.

Covering the period 1990-2001, the constructed tax rates indicate that taxes related to capital have fluctuated sharply, where such fluctuations can be attributed to policies regarding transfers, exemptions and the gradual relaxation of restrictions on capital flows. With respect to labour income, taxes reflect an increasing trend in response to better tax administration regarding the collection of income taxes as well as the increased entry of previously disadvantaged groups into formal sector employment. Only the effective tax on consumption exhibits a constant trend, a factor that can be attributed to the unchanged (since 1993) value added tax rate of 14 per cent and the zero rates imposed on basic foodstuffs.

\section{ENDNOTES}

1 Comprehensive data covering consumption taxes, and taxes on labour and labour income, as compiled in the South African Reserve Bank (SARB) Quarterly Bulletins, are available from 1990 and this year is taken as the starting period for constructing the effective tax rates.

2 For examples of studies using the King-Fullerton approach, see McKee et al. (1986) and the OECD (1991).

3 Transfers related to labour (and income) are zero (i.e. $\mathrm{b}=0$ ) as government is unable to create transfers per unit of labour (and capital) time. This point, combined with the fact that households are suppliers rather than consumers of labour services, means that the net consumption vector for labour is negative.

$4 \quad$ Razin and Sadka's (1993) discussion is based on a static model. They do, however, argue that in the single period (static period), savings (or future consumption) should be added to current consumption to obtain an indicator of lifetime consumption. Similarly, the government deficit (or future taxes) must be added to current tax revenues to obtain an overall tax measure. Under these conditions, Razin and Sadka postulate that the 
equilibrium of a dynamic economy will reduce to that of the static economy.

5 See Appendix A for the list of corresponding four digit codes identifying listed variables as used in the SARB Quarterly Bulletin.

6 Operating surplus is equal to the nation's gross output (valued at producer prices) less consumption of fixed capital, compensation of employees (including contributions to social security) and subsidies. As such, this definition of operating surplus bears an implicit assumption of aggregate constant returns to scale and zero net profits (Razin and Sadka, 1993).

7 Such comprehensive welfare schemes are taken in the context of western countries and include unemployment benefits, food stamps schemes, free or subsidised housing and education schemes.

8 This choice is informed by the fact that available funds for social grants are disbursed by governmental agencies.

9 Disadvantaged persons refers to persons classified as non-white during the apartheid era.

10 The effects of external factors such as the Asian crises of 1997 and the recent economic turmoil in Latin America (especially in Brazil and Argentina) on South Africa's exchange rate, asset (bonds and stocks) performance and capital flows serves to illustrate this point. 


\section{APPENDIX A}

Domestic taxes on goods and services [DTGS]: SARB Quarterly Bulletin series 4582.

Private final consumption expenditure [C]: SARB Quarterly Bulletin series 6007.

Government final consumption expenditure [G]: SARB Quarterly Bulletin series 6008.

Compensation of employees [GW]: SARB Quarterly Bulletin series 6256.

Taxes on income, profits and capital gains of households [THIP]: SARB Quarterly Bulletin series 6245.

Households' property and entrepreneurial income [PEI]: SARB Quarterly Bulletin series 6241.

Wages and salaries of households' [W]: SARB Quarterly Bulletin series 6240. Total social security contributions [TSC]: SARB Quarterly Bulletin series 4236. Taxes on payroll and workforce [TPW]: SARB Quarterly Bulletin series 4574. Taxes on income, profits and capital gains of corporations [TOC]: SARB Quarterly Bulletin series 6230.

Taxes on financial and capital transactions [TOFT]: SARB Quarterly Bulletin series 4576 and 4572.

Operating surplus of the economy [OS]: SARB Quarterly Bulletin series 6001. 


\section{REFERENCES}

1 AARON, H.J. \& SLEMROD, J. (1999) "The South African tax system: A nation in microcosm", Tax Notes, The Brookings Institute: www.brook.edu.

2 BARRO, R.J. \& SAHASAKUL, C. (1983) "Measuring the average marginal tax rate from the individual income tax", Journal of Business, 56(4).

3 EASTERLY, W. \& REBELO, S. (1993) "Marginal income tax rates and economic growth in developing countries", World Bank Country Economics Department, Series Papers 1050.

4 GREENWOOD, J. \& HUFFMAN, G. (1991) “Tax analysis in real business cycle model: On measuring Harberger Triangles and Okun Gaps”, Journal of Monetary Economics, 99.

5 JOINES, D.H. (1981) "Estimates of effective marginal tax rates on effective incomes”, University of Chicago Journal of Business, 54(2).

6 KING, M.A. \& FULLERTON, D. (eds.) (1984) The Taxation of Income and Capital: A Comparative Study of United States, United Kingdom, Sweden and West Germany, NBER, University of Chicago Press: Chicago, Illinois.

7 LUCAS, R.E. (1990) "Supply-side economics: An analytical review", Oxford Economic Papers, 42(2).

8 MASTERS, W. (2001) "The impact of capital flows to and from South Africa”, Southern African Update, March: 9.

9 MENDOZA, E.G., RAZIN, A., \& TESAR, L. (1994) "Effective tax rates in macroeconomics: Cross-country estimates of tax rates on factor incomes and consumption”, NBER Working Paper No 4864.

10 NOWAK, M. (2001) "The volatility of capital flows in South Africa: Some empirical observations”, Paper Presented at the BER Conference, Johannesburg.

11 RAZIN, A. \& SADKA, E. (1993) The Economy of Modern Israel: Malaise and Promise, The University of Chicago Press: Chicago, IL.

12 SEATER, J. (1982) "Marginal federal personal and corporate income tax rates in the United States: 1909-1975", Journal of Monetary Economics, 10(3).

13 SOUTH AFRICAN RESERVE BANK, Quarterly Bulletin, various years. Pretoria.

14 TANZI, V. \& ZEE, H.H. (2001) “Tax policy for developing countries”, IMF Economic Issue Series, No 27. 